\title{
Minding Our Business: Longitudinal Effects Of A Service-Learning Experience On Alumni
}

Cynthia M. Newman, Rider University, USA

Sigfredo A. Hernandez, Rider University, USA

\begin{abstract}
The mission of Minding Our Business (MOB), a service-learning course started in 1997 to meet community needs, is to advance the personal and vocational development of urban youth through entrepreneurship education and mentoring. This paper evaluates the long-term impact of $M O B$ on the personal and vocational development of the alumni mentors participating in the program from 1997 to 2005. No scholarly research has been conducted to date on the long-term effect of $M O B$ on mentors and little research has been conducted on the effects of service-learning participation on alumni service-related attitudes and behaviors in general. Consequently, the current study extends the existing research stream on the long-term effects of service-learning participation on alumni service-related attitudes and behaviors. Furthermore, the unique nature of $M O B$ as a mentoring program in entrepreneurship also allows the researchers to study possible long-term effects on interest in community service and interest in entrepreneurship as a vocational option.
\end{abstract}

Keywords: alumni attitudes; entrepreneurship education; service learning

\section{INTRODUCTION}

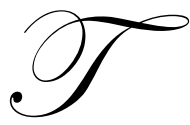

he mission of Minding Our Business (MOB), a service-learning course started in 1997 to meet community needs, is to advance the personal and vocational development of urban youth through entrepreneurship education and mentoring. Very few published accounts of service-learning efforts directed to the urban community reflect the integration of entrepreneurship education into the service-learning experience. The positioning of MOB, therefore, is quite unique among service-learning programs.

The course's creation was supported by a competitive grant from the College of Business Administration (CBA) at a private AACSB accredited university located in the northeastern United States. Because program congruence with the mission of the CBA was an important criterion in awarding the grant, the creation of the course and its learning goals were greatly influenced by the CBA's mission - to enable graduates to be socially responsible participants and to provide opportunities for experiential learning and programs to develop communication, interpersonal, teamwork, leadership, critical thinking and problem-solving skills. MOB provides CBA students with an opportunity to practice social responsibility while developing important life-work skills. Not only was fit with the CBA's mission important to securing the grant for the program's development, but also such fit is the first step toward successful institutionalization of a service-learning program (Morton and Troppe, 1996). Service-learning programs integrated into the central goals and mission of the schools and institutions in which they are based appear to have a greater chance of success (Kendall, 1990; Zlotkowski, 1998).

The purpose of this paper is to evaluate the long-term impact of MOB on the personal and vocational development of the college student mentors participating in the program from 1997 to 2005 . No scholarly research has been conducted to date on the long-term effect of this particular program on mentors and, in fact, little research has been conducted on the effects of service-learning participation on alumni service-related attitudes and behaviors 
in general. Consequently, the current study extends the existing limited research stream on the long-term effects of service-learning participation on alumni service-related attitudes and behaviors. Furthermore, the unique nature of $\mathrm{MOB}$ as a mentoring program in entrepreneurship allows the researchers to study possible long-term effects on interest in community service and interest in entrepreneurship as a vocational option as well.

\section{COURSE DESCRIPTION}

MOB is an elective service-learning course for CBA sophomores, juniors and seniors. The average class enrollment of 24 students is often evenly split in terms of gender. The course is taught only in the spring semester during afternoons, to coincide with the end of the school day at inner city schools. Mentors typically attend a 90 minute class one time per week and facilitate a weekly 90 minute program session with teams of middle school students (students) at inner-city partner schools.

The program works with students who are early adolescents, ages 11 to 14; typically, two-thirds of these students are female. More than ninety percent of the participating students are African American. Most students are from low-income families, with three-fourths of the students in the schools participating in the free or reduced lunch program (D.B. Wood, personal communication, February 28, 2005).

According to the Carnegie Council on Adolescent Development (1995) early adolescents are at a critical life-stage where they begin to engage in risky behaviors but are still susceptible to positive influences by an involved adult that would enable them to grow and become contributing members of society. This is the key reason for MOB to work with early adolescents. In addition, young adolescents who live in poverty are more likely to lack two crucial prerequisites for their healthy growth and development: a close relationship with a dependable adult and the perception of meaningful opportunities in mainstream society (Carnegie Council, 1995). Mentors, through their work in the MOB program, attempt to meet these two key prerequisites to student growth.

The mentors receive twenty hours of training at a weekend conference at the start of the semester for the purpose of: learning their role as mentors-facilitators, becoming familiar with the MOB curriculum, and getting to know their co-mentors. During the semester after the weekend-long conference, in-class learning activities help mentors prepare for their role as mentors/facilitators. During the class sessions, the mentors learn basic entrepreneurship concepts and how to facilitate the 12-week entrepreneurship curriculum at the partner school.

Since reflection is an essential element of service-learning (Godfrey, 2000; Howard, 2001; Jacoby, 1996; Mintz and Hesser, 1996), this activity plays a very important role in this service-learning course. The role of reflection in the pedagogy of MOB is best expressed by Jacoby (1996), "As a form of experiential education, service-learning is based on the pedagogical principle that learning and development do not necessarily occur as a result of experience itself but as a result of a reflective component designed to foster learning and development." Hence, reflection on the part of MOB mentors occurs in both the classroom and field experiences.

MOB learning goals for mentors are presented in Table 1. Two of the goals are affective-moral and refer to the practice of social responsibility and the respect that all mentors should develop for others. Three of the goals relate to the development of team, mentoring and communication skills. The remaining five goals are cognitive. These learning goals were designed with the intent of requiring mentors to de-emphasize memorization in favor of deep learning. Each of these five goals is followed by the highest thinking level required (in caps) based on Bloom's taxonomy of learning objectives (Bloom, 1956). Four of the five goals refer to the learning expected from helping inner city students to run a business. The remaining goal "practicing guidelines for the creation of an effective team" is important because the mentors are facilitating team businesses in the field and are themselves part of learning teams in the classroom. 
Table 1: Minding Our Business Learning Goals

The highest thinking level it requires or whether it refers to affective/moral or skill development follows each learning goal.

1. Develop a strong sense of social responsibility for the youth of the partner middle school. AFFECTIVE/MORAL

2. Understand the basic principles associated with the operation of an effective team. COMPREHENSION

3. Become a more effective team player. SKILL DEVELOPMENT

4. Develop mentoring and team facilitation skills. SKILL DEVELOPMENT

5. Improve leadership and communication skills. SKILL DEVELOPMENT

6. Develop sensitivity and respect for social class, ethnic and racial diversity. AFFECTIVE/MORAL

7. Understand some of the main issues and concerns of pre-adolescent development. COMPREHENSION

8. Apply the basic concepts of entrepreneurship to a student run business. APPLICATION

9. Facilitate the process of starting and running a business. APPLICATION

10. Set up a projected income statement for a small business. APPLICATION

Since the course creation in 1997, a cooperative learning pedagogy has been used in the classroom in a manner consistent with the team mentor concept applied in the field. In 1999 the instructor adopted the Instructional Activity Sequence (IAS) developed by Michaelsen (1994) for classroom use. In this model of cooperative learning, college students, not the instructor, cover the material outside class. Mentors are tested on key concepts when they come to class. IAS increases students' preparedness for applying the concepts that they have studied individually (Michaelson and Black, 1994). IAS also appears to improve mentor preparation to apply key mentoring, entrepreneurship and team concepts at the mentoring sessions and/or in class.

The team learning model used in the field portion of the course was originally adopted from the Princeton Center for Leadership Training in 1997, a non-profit organization specializing in the creation and operation of youth development programs. The mentoring experience is structured in the field through a 12-week activity-based entrepreneurship curriculum involving 13 program sessions. The sessions are: 1) Building a Team I, 2) Building a Team II, 3) Introduction to Entrepreneurship, 4) Selecting and Naming Your Business, 5) Pricing and Promoting Your Business, 6) Advertising that Works, 7) Your Business Plan, 8) Business Plan Presentations, 9) Getting Ready for Market Fair, 10) Market Fair, 11) Sharing Successes and Challenges, 12) Visit to Trenton Area Businesses, and 13) Reflections and Next Steps. The curriculum was developed in collaboration with the Princeton Center for Leadership Training. Each mentoring team facilitates a team of ten to fifteen middle school students through the process of starting and running a business. More than 100 students participate in the MOB program each year.

\section{EXISTING RESEARCH ON THE LONG-TERM EFFECTS OF SERVICE-LEARNING ON COLLEGE ALUMNI}

There has been little research on the long-term outcomes of service-learning programs including servicerelated attitudes and behaviors (Fenzel and Peyrot, 2005; Warchal and Ruiz, 2004)). Johnson (2004) indicates that future research must go beyond examining attitudes to understand the relationship between college experiences and behaviors: alumni cultural/political organization participation, and alumni service organization participation.

The existing research suggests that student participation in service-learning programs is often associated with positive long-term outcomes. The study by Astin, Sax, and Avalos (1999) shows that the effects of participation in college volunteer service persists up to five years beyond college graduation and are reflected in alumni's attitudes toward social responsibility and greater commitment to serving their communities. The research by Warchal and Ruiz (2004) indicates that participation in community service and service-learning predicted a greater likelihood of alumni choosing a job in a field related to the respondent's area of college service. The research by Fenzel and Peyrot (2005) suggests that student participation in both community service and service-learning is positively related to alumni attitudes toward personal and social responsibility as well as alumni involvement in community services and service-related careers. The study by Hart, et. al (2007) found that high school community service is a predictor of adult voting and volunteering.

Not all service-learning experiences produce the same outcomes. High-quality-service experiences are more likely to yield positive alumni outcomes. The study by Warchal and Ruiz (2004) found that alumni with a 
history of high-quality service-learning experiences were more likely to accept employment in service-related fields. Fenzel and Peyrot (2005) found that participation in community service and service-learning was positively associated with alumni attitudes toward social and personal responsibility as well as alumni involvement in postcollege community service and service-related careers. These findings were limited to courses that provided high quality experiences (more hours of service, more reflection activity, and more integration of service into the course).

\section{PRIOR RESEARCH ON THE MOB PROGRAM}

Research conducted by Hernandez and Newman (2006) on student outcomes supports the assertion that MOB is an excellent model for mentoring and service learning in entrepreneurship of young urban adolescents in the US. Research indicates that students in MOB become more interested in going to college and in starting their own businesses. Students participating in MOB observe positive changes in self and improvement in important work/life skills. Research on academic records data indicates that MOB participation reduces school absenteeism and tardiness. MOB also improves self-esteem among participating students. (Hernandez and Newman, 2006)

The study by Hernandez and Newman (2006) also indicates favorable short-term effects on Rider mentors. Mentors' reflections and end-of-program surveys provide evidence of a great learning experience and of the positive impact of MOB on their personal and vocational development. Most mentors characterize MOB as a great learning experience that cannot be compared with what is learned in other college courses. Mentors indicate experiencing significant learning about: self, the students, team and mentoring skills, and entrepreneurship. They report that MOB helps them prepare for the world of work, and that they would recommend MOB to their best friends.

In addition, MOB favorably influences mentors' vocational and personal interests. The majority of the mentors at the end of the program plan to do more community service and express a greater interest in working with kids in the future. Mentors clearly express an increased desire to include service to others in their career plans. A significant number of mentors also experience a greater desire to start their own businesses because of MOB. Through participation in the program mentors sample the process of starting and running a small business with their students; this experience often increases mentor interest in entrepreneurship as a career. MOB also helps mentors to understand poverty and to appreciate cultural differences (Hernandez and Newman, 2006).

While the many positive short-term impacts on both students and mentors support the value of MOB as a service-learning program, an indication of whether similarly positive long-term impacts exist would strengthen the value proposition of the MOB program even more. Hence, the current study was developed both to specifically evaluate the long-term impact of MOB on mentors and to generally add to the limited body of literature assessing the long-term impact of service-learning programs on college student participants once they are engaged in their professional and private lives post graduation.

\section{DATA COLLECTION INSTRUMENT}

In the current study, a two-page survey was developed covering a range of relevant areas to evaluate the long-term impact of MOB program participation on the college mentors once they became alumni. Specifically, the study was designed to evaluate whether participation in the MOB service-learning program during college impacted the graduates in the following areas:

- $\quad$ Choice of a profession that the practitioner believes contributes to society

- $\quad$ Community mindedness and engagement in community service

- $\quad$ Involvement with mentoring

- Development of life-work skills.

In addition to collecting descriptive information about current employment and community service involvement since the recipient's graduation from college and to asking directly about the impact of MOB participation on the areas listed above, the survey also incorporated items from two scales that had been previously developed and statistically assessed in areas related to the areas of interest to the study. One such scale was the Professionalism scale first developed by Hall (1968) and then revised by Snizek (1972) in order to evaluate 
respondent attitudes concerning the extent to which he/she believes his/her profession contributes to society. This scale was selected based on relevance to a projected impact of service-learning involvement on participants, namely pursuit of a career path that is personally considered to make a contribution to society as a whole. In previous applications, this scale demonstrated relatively strong reliability with a reported alpha of .715 (Snizek and Cocker, 1985). Another Likert-scale that was included was the Community Mindedness scale given the expectation that service-learning participation in college would carry over into community service involvement after college. In multiple item form, this scale was used in 1976 by Darden and Perrault (1976) and also used by several researchers in various configurations. These researchers demonstrated scale validity based on factor analyses and reported somewhat variable reliability as indicated by alpha values ranging from .65 to .824 (Dickerson and Gentry, 1983; Hawes, et. al., 1984; Lumpkin and Hunt, 1989). The complete survey is presented in the Appendix.

\section{FINDINGS}

\section{Respondent Background Information}

A total of sixty MOB alumni responded to the two-page survey out of the 235 mailed, yielding a response rate of $25.5 \%$. Of these respondents, $61 \%$ were male which is consistent with the male to female ratio of participation in the program. Respondents were distributed across the ten years that the MOB program has existed; however, alumni from the more recent years (2002- 2005) accounted for nearly two-thirds of the responses.

Attitude Toward MOB Experience

All but seven of the respondents $(86.9 \%, 53)$ reported that their learning experience in MOB compared "better" or "much better" to their learning experiences in other courses taken during college. Only one respondent did not respond to an open-ended item that asked respondents to share their most memorable MOB experience; and, only one respondent shared a negative remembrance. Fifty-nine respondents described a positive remembrance of their MOB experience. Several of these positive remembrances centered on the market fair event $(39.0 \%, 23)$ and on participating in a process that caused growth and attitude change in the middle school students $(30.5 \%, 18)$. In terms of establishing long-term relationships with the middle school children who were mentored, only nine (14.8\%) of the respondents indicated that they had communicated with any of the children they mentored since graduating from college.

\section{Community Service}

Community service has been part of the post-graduation experience of a majority of the respondents $(62.3 \%, 38)$. The average reported time spent in volunteer or community service activities during the previous year was 5.5 hours. Slightly less than one-third $(31.1 \%, 19)$ of the respondents are members of a community organization and one-fourth $(26.5 \%, 16)$ are members of a service organization, including hospitals, religious organizations, and community action groups. All but two respondents $(98.4 \%, 59)$ indicated that they plan to do community service in the future. Consistent with the active levels of participation in community service reported, nearly two-thirds of the respondents $(62.3 \%, 38)$ indicated agreement with the statement, "I feel I can have an impact on solving problems in my community." An even stronger majority $(83.6 \%, 51)$ indicated agreement with the statement, "Communities should provide social services to their members in need." The influence of the MOB experience on the community service leanings of the respondents is directly indicated by the following result: $91.8 \%$ (56) of the respondents reported that their MOB experience helped them either "some" or "a lot" in becoming "more caring about the poor and needy."

\section{Impact of MOB Experience}

In addition to exploring the areas of career and community service, the survey also inquired about the impact of the MOB experience on the respondents' career selection and preparation as well as skill development. Seventy-percent of the respondents (43) indicated that MOB had a favorable impact on their career plans with even more $(78.6 \%, 48)$ reporting that MOB helped to prepare them for the world of work. Six $(10 \%)$ of the respondents who explained the nature of the impact stated that their MOB experience either increased or confirmed their desire to work in their own or a small business. Another five respondents credited their MOB experience as being the reason they chose a career that involves working with children. 
The MOB experience also was viewed quite favorably by the respondents in terms of its impact on their development of skills and knowledge. Specifically, at least three-fourths of the respondents reported that their MOB experience had "some" or "a lot" of contribution to the development of their communication, team facilitation, entrepreneurship, mentoring and leadership skills (see Table 2).

Table 2: Impact of MOB on Skill Development

\begin{tabular}{|l|c|}
\hline \multicolumn{1}{|c|}{ Skill Area } & MOB Impact "some" or "a lot" (\%, n) \\
\hline Communication & $78.7 \%, 48$ \\
\hline Team Facilitation & $91.8 \%, 56$ \\
\hline Entrepreneurship & $77.7 \%, 47$ \\
\hline Mentoring & $88.5 \%, 54$ \\
\hline Leadership & $83.6 \%, 51$ \\
\hline
\end{tabular}

\section{Respondent Employment}

While slightly more than one-third of the respondents $(36.7 \%, 22)$ reported employment in a service related position, three-quarters of the respondents $(74.4 \%, 46)$ indicated that it was important to them personally to have a career that involved helping other people. Nearly one-quarter $(23.1 \%$. 14) of the responding MOB alumni have started a business since graduating from college while another approximately one-third $(31.1 \%$, 19$)$ of the responding alumni indicated that they are planning to start a business in the future. Even though only $11.5 \%$ (7) currently work with children as a part of their job, half of the respondents $(50.8 \%, 31)$ indicated that they plan to work with children or youth in the future.

\section{Continued Involvement with MOB}

Nearly $90 \%$ of the respondents $(86.9 \%, 53)$ indicated a desire to stay in contact with the MOB program. Three-fourths $(73.8 \%, 45)$ would like to continue to receive information about the program and approximately onethird $(36.1 \%, 22)$ would be interested in attending an "all mentor alumni reunion." Of those options for continued involvement with MOB that required a higher level of commitment, the most popular option was serving as a judge for the student business plan presentations $(42.6 \%, 26)$. This was followed in appeal by being a guest speaker $(29.5 \%, 18)$, providing financial support $(16.4 \%, 10)$ and becoming a mentor or becoming a tutor, both of which received interest from $14.8 \%$ (9) of the respondents.

\section{DISCUSSION AND CONCLUSIONS}

The present study suggests that a high quality service-learning experience in entrepreneurship like MOB appears to have positive long-term effects on young adults' attitudes, intentions and behaviors involving their learning experience, career selection, career preparation, skill development, and community service involvement.

The MOB experience is memorable as a quality learning experience among alumni respondents. Most respondents felt that their learning experience in MOB was better or much better as compared to other college-level courses. In addition, the vast majority of the respondents indicated that MOB had a favorable impact on their career plans as was evident in that a good number of respondents are employed in service-related positions, have started businesses or plan to start them in the future, and work with children or plan to work with children in the future.

As MOB students help develop the communication, leadership, team, and entrepreneurship skills of the children, they also appear to strengthen their own skills set. Most respondents recognized that the MOB learning experience had a significant contribution to the development of their communication, team facilitation, entrepreneurship, mentoring and leadership skills.

Finally, the MOB learning experience emphasizes the importance of social responsibility towards lowincome urban youth. That this impacted the students long-term was evident in that most MOB alumni reported that the service-learning experience helped them become more caring about the poor and needy. The finding that a 
majority of MOB alumni have practiced community service after graduation and plan to do community service in the future is supportive of the conclusion that the heightened sense of social responsibility gained from MOB participation is internalized by participants.

The findings of the current study support the assertion that the MOB program is a high quality servicelearning experience that has a long-term impact on the college students who participate as mentors. Furthermore, the nature of the impact of the experience is consistent with prior studies on the impact of high quality servicelearning programs (Astin, Sax, and Avalos, 1999; Fenzel and Peyrot, 2005; Hart, et. al, 2007; Warchal and Ruiz, 2004), which provides further support for the quality of the MOB program as one that allows students to internalize a sense of social responsibility while developing important life-work skills.

\section{LIMITATIONS AND FUTURE RESEARCH DIRECTIONS}

The main limitation of this study is that results may only be generalized to the type of service-learning course in entrepreneurship used in the research. A second methodological limitation was the use of a mail survey with a $25.5 \%$ response rate. This methodology raises questions about the characteristics of the alumni that did not return the surveys. Another limitation is that students who select a service-learning experience like MOB are generally more interested in community service. Thus, the direction of the relationship between the MOB servicelearning experience and community service, or MOB and plans to do more community service, is not clear.

Future research could strengthen the findings of this study by comparing the effects of the MOB servicelearning experience on MOB alumni with a control group of non-MOB alumni. A control group study would further clarify the long-term effects of the MOB learning experience on career selection, career preparation, skill development, and community service.

\section{AUTHOR INFORMATION}

Cynthia Newman received a Ph.D. (1998) in higher education administration from the University of Pennsylvania and an M.B.A. and B.S. in business administration from Rider University. She currently is Director of the Center for International Business and an Associate Professor of Marketing in the College of Business Administration at Rider University. In addition, she is on the leadership team for the Executive Center for Education and Development. Her areas of teaching expertise include strategic marketing planning and international marketing. Her research interests are in the areas of positioning and the scholarship of teaching and learning. E-mail: cnewman@ rider.edu

Sigfredo A. Hernandez received a Ph.D. (1988) in marketing from Temple University, an M.A. in economics from Boston University and a B.A. in economics from the University of Puerto Rico. He currently serves as an Associate Professor of Marketing in the College of Business Administration at Rider University and is the founding Director of the Minding Our Business service-learning program. His areas of expertise include team learning, mentoring and entrepreneurship education of urban youth, assessment learning and Hispanic consumer behavior. His research interests are in cooperative learning and student metacognitive skills. E-mail: hernandez@rider.edu

\section{REFERENCES}

1. Astin, Alexander W., Sax, L.J., and Avalos, J. (1999). Long-term Effects of Volunteerism During the Undergraduate Years. The Review of Higher Education, 22, (2), 187-202.

2. Bloom, B. S. (1956). Taxonomy of educational objectives: The classification of educational goals. New York: David McKay.

3. Carnegie Council on Adolescent Development. (1995). Great transitions: Preparing adolescents for a new century. New York: Carnegie Corporation.

4. Darden, William R. and Perrault, Jr., William D. (1976). Identifying Interurban Shoppers: Multiproduct Purchase Patterns and Segmentation Profiles. Journal of Marketing Research, 13 (February), 51-60.

5. Dickerson, Mary D. and Gentry, James W. (1983). Characteristics of Adopters and Non-Adopters of Home Computers. Journal of the Academy of Marketing Science, 13 (Spring), 271-289. 
6. Fenzel, L. Mickey and Peyrot, Mark. (2005). Comparing College Community Participation and Future Service Behaviors and Attitudes. Michigan Journal of Community Service Learning, 12, (1), 23-31.

7. Godfrey, P. C. (2000). A moral argument for service-learning in management education. In P.C. Godfrey and E. T. Grasso (Eds.), Working for the common good: Concepts and models for service-learning in management. (pp. 21-42). Washington, D.C.: American Association for Higher Education.

8. Hall, Richard H. (1968). Professionalism and Bureaucratization. American Sociological Review, 33 (February), 92-104.

9. Hart, Daniel, Donnelly, Thomas M., Youniss, James, and Atkins, Robert. (2007). High School Community Services as a Predictor of Adult Voting and Volunteering. American Educational Research Journal, 44, (1), 197-219.

10. Hawes, Jon M. and Lumpkin, James R. (1984). Understanding the Outshopper. Journal of the Academy of Marketing Science, 12 (Fall), 200-218.

11. Hernandez, Sigfredo A. and Newman, Cynthia M. 2006. Minding Our Business: A Model of ServiceLearning in Entrepreneurship Education. Journal of Entrepreneurship Education, 9, 53-75.

12. Howard, J. (2001). Academic service-learning: Myths, challenges, and recommendations. Teaching Excellence, 12, (3).

13. Jacoby, B. (1996). Service-learning in today's higher education. In B. Jacoby (Ed.), Service-learning in higher education. (pp. 3-25). San Francisco: Jossey-Bass.

14. Johnson, Danette Ifert. (2004). Relationships Between College Experiences and Alumni Participation in the Community. The Review of Higher Education, 27, (2), 169-185.

15. Kendall, J. C. (1990). Combining service and learning: An introduction. In J.C. Kendall (Ed.), Combining service and learning: A resource book for community and public service. Raleigh, NC: National Society for Experiential Education.

16. Lumpkin, James R. and Hunt, James B. (1989). Mobility as an Influence on Retail Patronage Behavior of the Elderly: Testing Conventional Wisdom. Journal of the Academy of Marketing Science, 17 (Winter), 112 .

17. Michaelsen, L. K. (1994). Classroom organization and management: Making a case for the small group option. In K.W. Prichard \& R. M. Sawyer (Eds.). Handbook of college teaching: Theory and application. (pp.). Westport, CT: Greenwood.

18. Michaelsen, L. K. and Black, R. H. (1994). Building learning teams: The key to harnessing the power of small groups in higher education. In S. Kadel \& J. Keehner (Eds.), Collaborative learning: A sourcebook for higher education. (pp.) State College, PA: National Center for Teaching, Learning and Assessment.

19. Mintz, S. D. and Hesser, G. W. (1996). Principles of good practice in service-learning. In B. Jacoby (Ed.), Service-learning in higher education. (pp. 26-52). San Francisco: Jossey-Bass.

20. Morton, K. and Troppe, M. (1996). From the margin to the mainstream: Campus compact's project of integrating service with academic study. Journal of Business Ethics, 15, 21-32.

21. Princeton Center for Leadership Training (1997). Minding our business: Team mentor advisor handbook. Princeton, NJ: PCLT.

22. Snizek, William E. (1972). Hall's Professionalism Scale: An Empirical Reassessment. American Sociological Review, 37 (Februrary), 109-114.

23. Snizek, William E. and Crocker, Kenneth E. (1985). Professionalism and Attorney Attitudes Toward Legal Service Advertising. Journal of the Academy of Marketing Science, 13 (Fall), 101 -118.

24. Warchal, Judith and Ruiz, Ana. (2004). The Long-term Effects of Undergraduate Service-Learning Programs on Postgraduate Employment Choices, Community Engagement, and Civic Leadership. In New Perspectives in Service-Learning: Research to Advance the Field, 87-106.

25. Zlotkowski, E. (1998). Introduction: A new model of excellence. In Successful Service-Learning Programs: New Models of Excellence in Higher Education, E. Zlotkowski (Ed.). Bolton, MA: Anker Publishing Company, Inc. 


\section{APPENDIX}

\section{MINDING OUR BUSINESS ALUMNI MENTORS SURVEY}

\section{CURRENT EMPLOYMENT}

1. Are you currently employed in a service-related job (e.g., education, nonprofit, govemment, social work, health care)?

O Yes

O No, employed in another industry sector

O No, I am not currently employed

2. What is your job title?

3. Briefly describe what you do in your current position

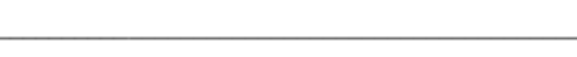

4. Do you work with children or youth as part of your job?

o Yes

O No

5. Are you planning to work with children or youth in the future?

o Yes

O No

6. Have you started a business since you graduated from Rider?

OYes ONo

7. Are you planning to start a business in the future?

OYes ONo OMaybe

8. The referent in the following items is your own profession. If the item corresponds very well to your own attitudes and/or behavior, mark "very well". If it corresponds well, poorly or very poorly, mark the appropriate response. The middle category is designed to indicate an essentially neutral opinion about the item. Please answer all of the items.

Very well
$\begin{gathered}\text { Other professions are actually more } \\ \text { vital to society than mine. }\end{gathered}$

\section{COMMUNITY INVOLVEMENT}

9. Have you done any community service since graduation?

o Yes

O No

10. Approximately how many hours of volunteering or community service have you done in the last 12 months?

\section{O None}

11. Are you a member of any community organizations?

o Yes

ONo

If yes, which one(s):

12. Since graduating from Rider, have you participated in a service immersion experience such as Americorps or the Peace Corps.

o Yes

O No

13. Are you planning to do any community service in the future?

O Yes

O No

O Maybe

14. Please indicate the extent to which you agree or disagree with the following statements as they pertain to your current level of activity.

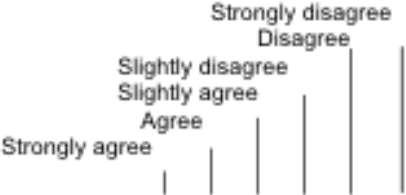

I am an active member of more than one service organization. I do volunteer work for a hospital or service organization on a fairly regular basis.

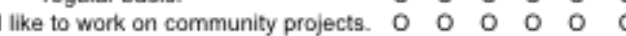
I am an active member of more than one social organization or religious organization.

I do volunteer work on a regular basis. 


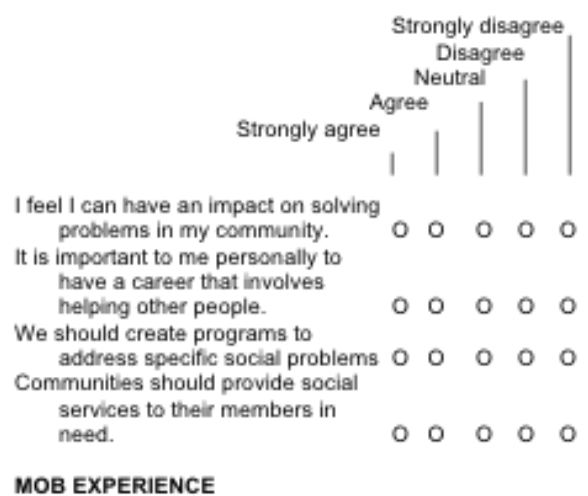

15. What was your most memorable experience in MOB? Why?

16. How did your leaming experience in MOB compare to the learning experience in other courses that you took at Rider?

$\begin{array}{ll}\text { O Much worse } & \text { O Better } \\ \text { O Worse } & \text { O Much better } \\ \text { O Same } & \end{array}$

17. Did $M O B$ have a favorable impact on your career plans?
o Yes
O No

Please explain your response.

18. To what extent did your experience in MOB help prepare you for the world of work?
O Not at all
O Some
O Very little
O A lot

19. To what extent did your experience in MOB help you become more caring about the poor and the needy?

$\begin{array}{ll}\text { O Not at all } & \text { O Some } \\ \text { O Very little } & \text { O A lot }\end{array}$

20. Have you mentored another person (of any age) since graduation?

o Yes

O No
21. To what extent did MOB contribute to your development of the following life/work skills?

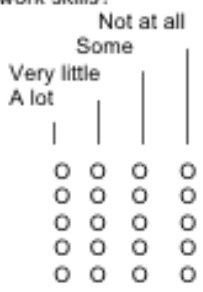

22. Have you communicated with any of the kids you mentored after graduation?

o Yes

O No

If yes, by what method? (Mark all that apply.)

$\begin{array}{ll}\text { O Mail } & \text { O In person } \\ \text { O Telephone } & \text { O No contact } \\ \text { O E-mail } & \end{array}$

23. Are you still in touch (at least once a year) with any of the kids that you mentored through MOB?

O Yes

O No

If yes, approximately how often are you in touch?
O Once per year
O Four times per year
O Twice per year
O Five times per year
O Three times per year O Six times or more per year

24. Would you be interested in staying in touch with the program?

o Yes

O No

If yes, what relationship would you like to maintain with the program? (Mark all that apply.)

O Receive information about the program

O Be a judge to business plan presentations

$\mathrm{O}$ Be a guest speaker

O Become a mentor

O Become a tutor

O Provide financial support

O Attend an all mentor alumni reunion

25. Are you... O Female O Male

26. What year were you in the MOB Program?

$\begin{array}{ll}O 1997 & O 2002 \\ O 1998 & O 2003 \\ \text { O } 1999 & O 2004 \\ \text { O 2000 } & O 2005 \\ \text { O 2001 } & \end{array}$

27. What are you plans with respect to a graduate degree?

O Have obtained a graduate degree

O Currently pursuing a graduate degree

O Planning to pursue a graduate degree

O Not currently planning to pursue a graduate degree 